\title{
Recruiting a Scientific Enigma: Ramsay Wright at the University of Toronto and its Reconstituted Medical School, 1874-1912
}

\author{
John P.M. Court
}

\begin{abstract}
Ramsay Wright was appointed in 1874 to the University of Toronto's Chair in Natural History through an advertised competition designed to replace patronage with adjudicating candidates on merit. An absence of transparency and inconsistencies in the outcome, however, provoke doubts that the process was pursued fairly to acquire the most qualified candidate. Premier Mowat passed over eminently-qualified Canadians for this inexperienced Edinburgh lab tutor. The Darwinian orientation of his education together with training in the German scientific research methods, although sub rosa criteria because of their political contentiousness, appear to have been decisive for Wright's selection. From archival evidence this study contrasts the recently-enacted protocol for fair, objective faculty recruitment with the shadowy process through which Wright was chosen. Once installed, with sparkling lecturing skills and the benefit of mentoring Wright sidestepped his modest research output to progress in administration. Passed over for Toronto's presidency, he diverged to embrace a later-discredited aspect of evolution, advocating publicly for human eugenics. Wright retired to Oxford in 1912, after which the more engaging aspects of his persona were periodically burnished for the university's commemorative contexts.
\end{abstract}

RÉSUMÉ

Ramsay Wright fut nommé titulaire de la chaire d'histoire naturelle de l'Université de Toronto en 1874 , lors d'un concours public conçu pour remplacer le favoritisme par un processus de sélection basé sur les mérites des candidats. Cependant l'absence de transparence et des incohérences dans le résultat mirent en doute l'impartialité du processus de sélection. Le premier ministre Mowat préféra ce chargé de travaux pratiques inexpérimenté d'Édimbourg à des Canadiens éminemment qualifiés. L'orientation darwinienne de l'éducation de Wright et sa formation dans les méthodes de recherches scientifiques allemandes, bien qu'il s'agisse de critères confidentiels en raison de leurs caractères controversés, semblent avoir joué un rôle décisif dans le choix de Mowat. À partir de documents d'archives, cette étude oppose le nouveau protocole mis en place pour assurer un recrutement juste et objectif à l'obscur processus par lequel Wright fut sélectionné. Une fois installé, celui-ci se révéla un conférencier brillant et il compensa son modeste rendement de chercheur en progressant dans l'administration. 
This paper explores a mysterious quandary: why was the young, inexperienced and locally unknown Robert Ramsay Wright (1852-1933) selected for a professorship at the University of Toronto in 1874, in the face of competition from others considerably more qualified and better known? His application file, which might have provided clues, has not survived. We know that two leading authorities whose support could have swayed the competition in Wright's direction did not write; and no rationale or explanation for his selection was articulated.

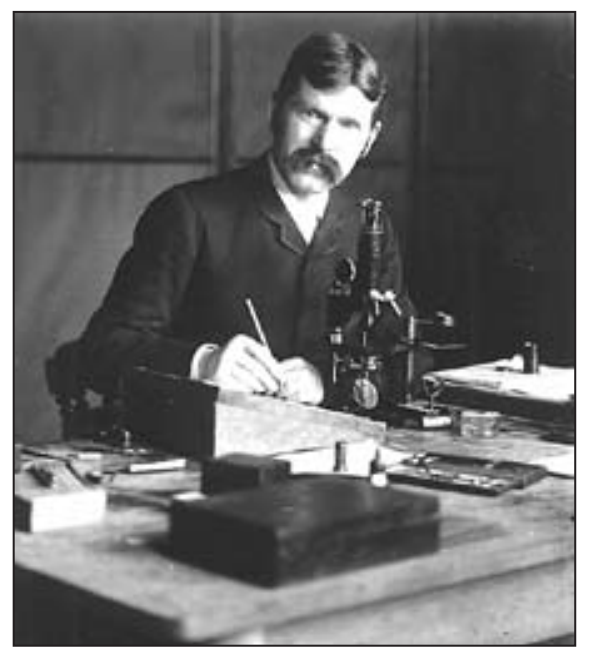

Fig. 1: Professor Ramsay Wright in his lab at Toronto, ca.1880, (UTA, B2000-0024/002P(06), glass lantern slide).

An open competition was advertised in 1874, in the midst of the University of Toronto's (U. of T.) tumultuous ideological and political landscape, to fill the Chair in Natural History — vacated after a scant three years by its second British incumbent, the prolific Henry Alleyne Nicholson. An article that year summarizing his recent scientific discoveries, many involving Ontario's Great Lakes, concluded that: "He was a man of no common attainments before ever he saw our shores, and his sojourn in this country has added largely both to his knowledge and his reputation." ${ }^{1}$ The outcome of Toronto's 1874 competition held the prospect of a spark for invigorating botany while maintaining Nicholson's considerable momentum in zoology and palaeontology — for example, by establishing the aborted U. of T. botanical gardens. ${ }^{2}$ Instead, it resulted in delaying meaningful progress on that front for thirty-five years. The winner, Robert Ramsay Wright, M.A., B.Sc., came to enjoy a favourable regard from almost everyone except the university's botanists, whose criticisms had to be discreetly restrained. ${ }^{3}$

The philosophical-scientific paradigm for which Wright was plucked from obscurity to champion in Toronto's was then controversial and, to a much lesser extent, remains so. In April of 2006, Toronto's Globe and Mail reported that creationism and intelligent design were moving northward across the U.S. border to challenge the Darwinian bulwarks of evolution and natural selection. ${ }^{4}$ The fact that evolutionism, as Darwinism became known from the 1870s, and religion have coexisted 
harmoniously in Canada owes much to a tolerance of conflicting viewpoints within institutions of learning and a tradition of separating spiritual faith and practice from science and nature. When Wright as biology head at the University of Toronto authored Ontario's first high school zoology textbook in $1889^{5}$ — which was widely distributed, as the Ontario Education Department's early textbooks generally were, elsewhere in English-speaking Canada ${ }^{6}$ - he gave prominent and favourable mention to Charles Darwin and his collaborator, Alfred R. Wallace. The nub of their evolution postulates was concisely introduced as scientifically fundamental, without reference to opposing explanations or controversy.

Evolutionist principles were well-established in certain prominent foreign biology texts for schools and public audiences, prepared over the preceding three decades by standard-bearing Darwinian giants of science education, Professors T.H. Huxley, Henry Newell Martin of Johns Hopkins and Harvard's Asa Gray. Identifying Darwin or his collaborators in Canadian pre-university texts was, however, still not then customary. Yet Wright cited Darwin by name and incorporated a schematic world map that charts the "Zoogeographical Regions, after A.R. Wallace," also locating "Wallace's line." Teaching biology to arts, engineering and medical students while helping to reestablish his university's medical school, Wright and his sponsoring provincial education officials gradually secured a beach-head for evolution in Canadian schools.

\section{Science at Toronto Before Ramsay Wright}

Charles Darwin's The Origin of Species by Means of Natural Selection (1859) launched a tectonic shift in the history and philosophy of science. The challenge was set squarely before natural science, still deeply infused with religious beliefs, to set aside what had literally been Holy Writ and consider in altogether novel ways how human beings and all living things had evolved. At that same time the German research ideal was also finding favour for advancing knowledge through testing scientific hypotheses under controlled conditions. This was certainly the view of one of the defining influences on Wright's career, Dr. William Osler, whose early education in Ontario had been steeped in the traditional religious approach to science. Osler had long since migrated to Darwinism, and championed the value of laboratory-based research, when he advocated "interrogating" as well as observing nature, to harness "the value of experiment as an instrument in the progress of knowledge." 8

The acceptance of such progressive thinking, however, was gradual and sporadic in Darwin's British homeland, and even slower abroad. ${ }^{9}$ Many in the anti-Darwinist camp shifted with care and discretion towards the progressive camp, including U. of T. President Daniel Wilson. In 1887, two years before Wright's high school textbook was published, still shuddered at the prospect of public confrontations with the distinguished Darwinian visitor, Alfred Russel Wallace, scheduled to speak on campus. "The very title of his first lecture, 'Darwinism,' is enough to bring the clergy down on us in full force," Wilson fretted, "for the very name of Darwin is to most of them like a red flag to a bull; and the greater their ignorance the more pronounced their dogmatism." 10 
From the 1880 s, livestock breeding scientists, zoologists and medical researchers showed interest in the draconian eugenic agendas that were spun off from Darwin's natural selection theories into social Darwinism by his cousin, Francis Galton and the social evolutionist, Herbert Spencer. Most Canadian academics were cautious observers of the evolution debates, as were the field botanists. Among evolution's vocal opponents in Canada, the foremost was Principal J.W. Dawson of McGill who "threw himself into a defense of the traditional natural history with a zeal that was obsessive." Dawson earned "a reputation as the most distinguished anti-Darwinian in the English-speaking world.” Toronto's Natural History Professor William Hincks was staunchly, if less stridently opposed, as was the more influential Professor Daniel Wilson, until by 1873 he had largely accepted the evolutionists' case. ${ }^{11}$

By coincidence, that same year also saw the passage by Oliver Mowat's provincial Liberal government of a university reform bill, promoted by a cadre of young Grits who had graduated from U. of T. between 1854 and 1863 . They were led by two lawyer-politicians: Mowat's predecessor as Premier, Edward Blake; and Adam Crooks, the university's volunteer Vice-Chancellor since 1864 and a member of the 1871-72 Blake government. The Senate Reform Act ("Crooks Act”) of 1873 not only removed all representation by the rival denominational colleges (Victoria, Queen's, Knox) but required the election by U. of T's own graduates of the Chancellor and fifteen alumni to its senate. ${ }^{12}$ Among the first to be elected were former Premier Edward Blake - also a leader of the nationalistic Canada First movement; Thomas Moss, who was also a lawyer and Federal M.P. in Alexander Mackenzie's Liberal government, elected as the university's Vice-Chancellor that year; lawyer William Mulock, thereafter a recurrent $U$. of T. volunteer administrative officeholder; and physicist James Loudon, a U. of T. tutor since 1863, a devotee of the German research ideal, Toronto's future professorial chair in physics (1875) and President from 1891 to 1906. His nephew would later proclaim that: "The old regime and its mediaeval methods were beginning to disappear." 13

William Mulock ranted against the teaching style of their former professors of Natural History (Hincks) and Natural Philosophy (J.B. Cherriman). While Osler made clear that his experiences with Hincks's tutelage and mentoring in field and lab biology were positive, Mulock claimed that: "Prior to 1876 the subjects of Natural History and Zoology were taught in the lecture room upon a blackboard.... Botany and Zoology were studied with the aid of books, filled with long and tedious lists. One large binocular microscope... of 1851, was the only sign of modern progress." 14 Loudon expressed a similar view, recalling that Hincks "was much given to the work of classification" and "success of a student in his Department depended largely on memorizing." ${ }^{15}$ Other friction of a non-paedagogic sort heated the steamy political cauldron through a bizarre legislative twist imposed in 1873 on the Provincial University (as it was designated), until 1906. All professorial appointments were made, not by its president whose position was "consistently undermined," but exclusively by the Government. Moreover, while nominally appointed by the Minister of Education, senior academic officeholders frequently emerged through lobbying campaigns directed higher still, to the Premier. ${ }^{16}$ 


\section{Faculty Recruitment at Toronto after 1849}

Procedures in nineteenth-century Ontario for appointing public officeholders had long been based on British Imperial patterns of socio-political patronage. Appointments were decided through protocols or customs by elite officeholders, in a delegated patronage model emanating downward from the reigning monarch at its pinnacle. Patronage holders exercised their privileges under various laws and customs that often encompassed the rebate of a proportion of an appointee's emoluments (generally in the initial year) to the appointing patron. ${ }^{17}$ They maintained control or influence over the choice of candidate and the manner in which selected incumbents would carry out their functions, while also earning income from this prerogative.

The official exception to public appointments conferred as-of-right by highranking elites arose much sooner and more formally than is generally thought: at midcentury, within the higher education sector, with passage of the 1849 Baldwin Act for reconstituting the Anglican King's College as the secular University of Toronto. ${ }^{18}$ This statute reflected the determination of the ruling Reformers to secularize the university under state control, in the wider context of a movement for democratizing education that followed from the Enlightenment and reactions to the French Revolution. The nineteenth century state university arose in support of nationalism, liberalism and industrialization, following the lead of secular universities founded at Berlin (1810) and London, U.K. (1826). ${ }^{19}$ Sociological theorist, Max Weber (1864-1920) later posited that formal organizations (bureaucracies) act impartially and rationally when they administer (as in recruitment) by means of ethical universalism. Universalistic criteria are openly declared, objective standards, applied fairly and accountably — as opposed to employing particularistic criteria - i.e., a covert agenda of unofficial, individualized criteria or of personal bias. ${ }^{20}$

The restructured Provincial University's ultimate selection decisions, formerly the prerogative of the Governor General, now moved into the ambit of the Premier (and later to the Education Minister) in the spirit of Lord Durham's Responsible Government reforms. More uniquely, and anticipating Weber, was the introduction of a process requiring a public advertisement, to be followed by peer review for ranking by merit. Through screening the respondents to identify the three most-qualified, with the option from 1850 of supplementing those applicants with consenting nominees, a short list was to be developed by the university's academic leaders (the Caput), ranking the referred candidates "in the order of qualification and merit." ${ }^{21}$ With the university senate's approval, this ranked list was sent on to the Premier as formal advice, from which he was required to make his selection. With minor adjustments that protocol remained in place until 1906, when Premier Whitney made Toronto's last unilaterally political appointment.

Toronto's recruitment administrators could sometimes also look to examples of ostensibly fair and disinterested processes at other academies. In the year prior to the Natural History competition, Victoria College's board empowered President Egerton Ryerson to search for "a first-class Professor for the chair in Natural Science" while he toured British and European institutions. In June of 1874, Toronto's Daily Globe 
reported that Ryerson had successfully recruited Dr. Eugene Haanel from Breslau, "a great acquisition to the teaching staff" in their Methodist Church sponsors' view - and with whose expertise they later opened in 1877 the first post-secondary science building in the province. ${ }^{22}$

Yet from the archival evidence, the aim of establishing open and fair academic recruitment based on a primacy of qualifications and merit was not always so successfully realized. Professor A.B. McKillop argued that individual factors of background and connections continued to hold sway in this era. "Family ties and letters of recommendation by scholarly acquaintances, not the open market-place of academic competition for posts, dominated academic hiring at the time." 23 Drilling below the surface in the case of Ramsay Wright reveals a puzzling mystery as to how and why he was chosen, since neither the model of competitive merit nor that of insider connections seems to have held sway. From the surviving archival evidence, the conclusion is inescapable that criteria reflecting qualifications and merit were modified in putting forward the short-listed candidates, such that evidently the least-qualified of the seven candidates was chosen. Available indications point to a situation of covert qualities having assumed priority in this competition over those that reflected merit - with an outcome of mixed results, over the long term. How and why, then, was Wright selected as Toronto's new Professor of Natural History?

\section{Ramsay Wright or Wrong? A Perplexing Academic Selection Process}

Surviving details of the 1874 competition are sketchy. None of those who were passed over recorded mention of it, as Thomas Huxley and John Tyndall had memorably done after losing their respective U. of T. competitions in the 1850 s. $^{24}$ Toronto's new alumni members were just settling into their new positions of power through the previous year's Crooks Act. Despite their motivating agenda as primarily to focus on securing Canadian-born appointees, this selection was concluded in favour of Wright - an unknown, recent graduate from abroad. Not until the following year when the alumni faction encouraged their choice, James Loudon, to make a spirited (and successful) run for the retiring Prof. Cherriman's Natural Philosophy vacancy, did they begin to flex political muscle in pursuit of securing Toronto's first homegrown chair. ${ }^{25}$

When Alleyne Nicholson cut short his brief Canadian career as Natural History chair early in 1874, moving on to the Royal College of Science in Dublin, the announcement of his new appointment there quickly stimulated pre-emptive inquiries as to whether a Toronto vacancy had been created. ${ }^{26}$ The Provincial Secretary advertised the position during April. Seven applications were received and referred directly to Premier Mowat. Four of them, including Wright, were minimally or moderately qualified. ${ }^{27}$ The other three were quite well qualified. Among the latter was the Canadian-born Robert Bell from the Geological Survey of Canada (GSC), just 33 years of age, who provided a printed booklet of glowing testimonials. Three of those came from eminent geologists who were his mentors - Principal Dawson of McGill, Sir William Logan of the GSC and Prof. E.J. Chapman of U. of T. Bell had 
held the Chair of Chemistry and Natural History at Queen's for four years in the 1860s. In another testimonial likely targeted to the university's rising "nativists," the GSC paleontologist and founder of The Canadian Naturalist and Geologist journal, Elkanah Billings, wrote that: "Mr. Bell is by birth, education and sympathies a thorough Canadian and the varied qualifications that he possesses [for the U. of T. position]... are not combined in any other person that I know of." 28

Secondly, applying from Edinburgh's Natural History Laboratory with botany and zoology specializations was Robert Brown, M.A., Ph.D., F.L.S. (Fellow of the Linnaean Society). Dr. Brown was a year younger than Bell, more academically qualified than both Bell and Wright, and had enjoyed at the Universities of Edinburgh and Glasgow ten more years of direct experience than Wright. A letter of reference mailed directly to Queen's Park by an Ottawa physician supported Brown's candidacy. ${ }^{29}$

Most surprising from the available evidence is that the third of these three highlyqualified candidates, Professor George Lawson (1827-1895), D.Litt. (Giessen, Germany), LL.D. (Hon. McGill) was ultimately passed over. Lawson had demonstrated enterprise as the first 19th-century scientist to launch a Canadian university botanical gardens, at Queen's - short-lived due to his departure three years later. ${ }^{30}$ Now aged 47, Lawson's application was supported by 29 impressive testimonials which (like Bell's) were printed as an enclosure pamphlet with his April, 1874 application letter to the Provincial Secretary. ${ }^{31}$ The Chief Justice of Nova Scotia, Sir William Young, typified the sentiments of Lawson's contemporary superiors and colleagues at Dalhousie University through his testimonial as Chairman of their Board of Governors:
Dr. George Lawson was appointed Professor of Chemistry and Natural History in Dalhousie College ten years ago. The Governors have had good cause to congratulate themselves ever since on having then secured the services of so distinguished a scientific man, and so successful a teacher of youth. They now regret that he should even contemplate removing from Halifax, as it would be difficult to fill the Chair of one who occupies a first place in the esteem of every one connected with Dalhousie College, not only for efficient discharge of his regular duties, but for courtesy of manner, and for public services of various kinds. ${ }^{32}$

A veil of mystery still obscures whatever winnowing process ensued that culminated with the announcement early in September,1874 of Wright's selection. The candidates' documentation (with the possible exception of the missing Wright file) do not reveal the existence of scoring or ranking efforts, other assessment procedures, nor any indication of a rationale for the outcome. Also puzzling is why the premier should have assumed the working lead for processing the applications when he already enjoyed decision-making power. Mowat had become a lawyer through apprenticeship without attending university, hence was not one of the young, reform-minded U. of $\mathrm{T}$. alumni in its senate; nor was this a senior administrative post of the sort that usually aroused ministerial interest. Prof. Daniel Wilson later opined privately (and 


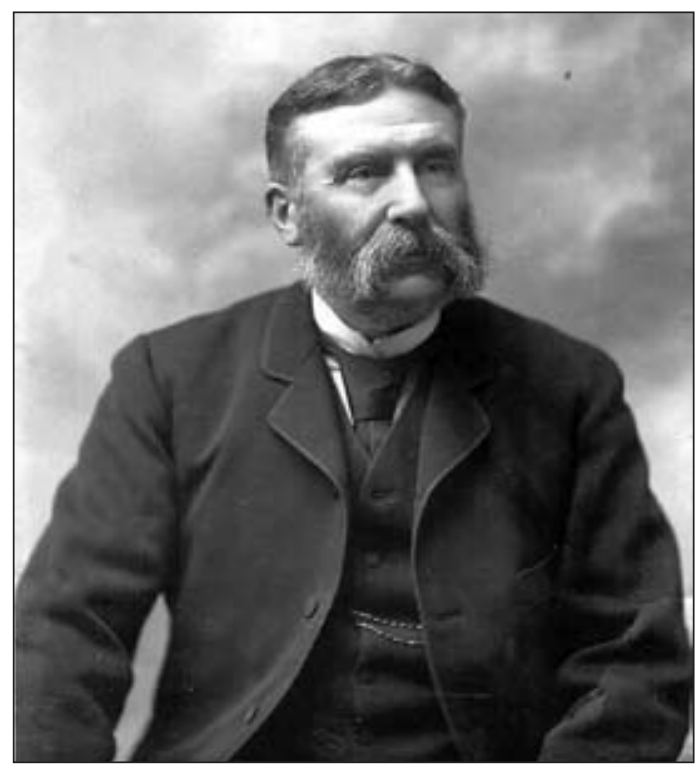

Fig. 2: Professor George Lawson (Dalhousie University Photo Collection, PC1, Box 16, File 112).

caustically) of this premier that "his policy has never been to lead; but to find how the current sets, and swim with the tide." Chatting informally during April with Mowat about the competition, Wilson learned that Mowat intended to disregard the sub rosa machinations of two other senate members, President John McCaul and Adam Crooks. Thereafter, based on his personal diary, Wilson appears to have had no further input to the selection decision. ${ }^{33}$

The 22-year-old Wright was so out-matched by Professor Lawson's quarter-century advantage of directly relevant qualifications and experience - 16 years of which were spent in equivalent positions at two other Canadian universities - that the conclusion is inescapable that other considerations were allowed to prevail over merit and academic interests. In this instance, based on the fact that the three objectively most qualified candidates were passed over, for whatever reasons, the customary universalistic criteria for such competitions clearly were set aside or overruled, along with the emerging, controversial criterion that candidates be of Canadian origin.

What, then, did Robert (as he was known in Scotland) Wright have to offer that the others did not? Fundamentally he was a fresh face, devoid of baggage from Canada's turbulent university politics. The alumni bloc in the senate, along with Daniel Wilson as one of U. of T's defenders, well remembered the Parliamentary Hearings of 1860-63 when, as undergraduates, they had turned out to support their alma mater against the acrimonious attempt to plunder its endowment led by two of the sectarian colleges, Victoria and Queen's. Spearheaded by Egerton Ryerson, the external raiders rubbed salt in this wound by manoeuvring from their legislated seats within Toronto's own senate. In 1860 the sectarians had secured the election as Vice-Chancellor of James Patton, "a tool of the Methodists." The undergraduates, "led into battle" by Blake and Crooks, later jeered the "moles" and denounced Patton at an 1863 public meeting 
with "three groans for the Vice-Chancellor." ${ }^{34}$ Eleven years later, and just one year after the 1873 Crooks Act had finally abolished the sectarian colleges' senate seats, the resentment against them, as disloyal senate members harbouring a counter-allegiance to the university, remained vivid. Hence the key university players, notably Wilson (who fretted in his diary about moles) and the premier's coterie of alumni advisors, would have been leery of endorsing candidates Lawson and Bell who, however meritorious, had formerly held faculty positions during the Queen's rivalry.

Robert Bell claimed to the Rev. John Mowat, in a private letter pleading for the Mowat brothers' personal intervention, that it was necessary to offset "certain extravagant assertions which were being made in favour of another candidate, Dr. R. Brown of Scotland whose special merit consists in the fact that he has been of service to Prof. Nicholson, who wished to reciprocate." Robert Brown's candidacy was indeed closely associated with Nicholson, whose support came not just through a testimonial but as well via a letter of endorsement for Brown that Nicholson sent in directly. ${ }^{35}$ Since this rivalry between these two candidates may have been Robert Brown's only blemish, the cautious premier seems to have hesitated at the prospect of re-introducing Brown to Toronto as a "formidable rival" 36 who might continue to provoke Bell's peevish enmity from his stronghold at the GSC.

\section{Wrightly or Wrongly, Ramsay Gets the Nod}

Young Robert Ramsay Wright, on the other hand — struggling unexceptionally on the other side of the Atlantic to launch his career - was evidently a complete unknown to the academics and government officials who were directly involved with the competition. Nevertheless he implicitly offered them two other attributes that we know would have struck a chord with several of Toronto's influential senate alumni members. He was the only candidate educated entirely during the post-1859 Darwinian era - moreover, at a university, Edinburgh, that was known to have "absorbed" the theory of evolution. ${ }^{37}$ Secondly, Wright was untarnished by association with either the known anti-Darwinians such as McGill's Principal Dawson, or with U. of T's rival sectarian colleges.

Within U. of T., James Loudon was by then the most clearly recognizable supporter of Darwin, evolution and the German research ideal. He and his alumni cohorts had long chafed in their perception of having had to burrow through mindnumbing memory work in their science courses. Hence Loudon much later expressed his pride in having spearheaded Toronto's "movement in favour of practical instruction in the sciences" which "may be said to have begun in 1874 , with the adoption of a resolution in the Senate of the University in favour of making laboratory work obligatory in the undergraduate science course. In pursuance of this policy, it became necessary to establish and equip laboratories which would afford facilities for this purpose." 38 To make best use of the new instructional labs, Loudon would likewise have deemed it necessary in that same year to lobby for the recruitment of a suitably progressive (i.e., evolutionist), research-oriented and laboratory-savvy successor to Hincks and Nicholson. 
Darwinism seems to have been a factor in this job competition in other ways. The deeply ambivalent reactions in Canada to natural selection and related evolution issues slowly began to solidify after 1871 , in response to Darwin's second major publication, The Descent of Man. Some, such as Principal Dawson, redoubled their vigorously idealistic criticisms of evolution. Others, more moderately, explored a reconciliation. The leading supporter of Darwinism among those arguing outside of Canadian universities, through literary and intellectual magazines (notably the Canadian Monthly and National Review), was William Dawson LeSueur. As it transpired, LeSueur was also a former undergraduate contemporary of James Loudon, both at U. of T. and (briefly for both during 1862) at Osgoode Hall. Commencing in 1871, LeSueur was prolific, formidably gifted and forthright as a literary critic and philosophical commentator. He recognized the profound significance of evolution, foresaw its inevitable influence and, like Loudon at U. of T., did not shrink from arguing its case. ${ }^{39}$ Three of the candidates - Bell, Kemp and Lawson - had associated themselves with the English-speaking world's pre-eminent anti-Darwinian, Principal Dawson. Although Wright was an unknown outsider, he at least was not tarred by that conservative brush.

Closing the alumni circle of shared U. of T. experience and like-minded interest in influencing this decision was the aforementioned, distinguished Liberal Member of Parliament, Thomas Moss - a partner in the law firm where Loudon had worked while at Osgoode, a close ally of Edward Blake, and a leading legal educator. In 1874, Moss became the university's Vice-Chancellor, orbiting comet-like toward judicial appointments that culminated for him in 1878, at age 41, as Chief Justice of Ontario. He was regarded, in Wilson's words, as "a man of clear intellect, sound judgment and sterling integrity." ${ }^{40}$ Moss and Edward Blake were at the time consistent allies and advisors to Loudon and Mulock, who would call upon them at crucial times to influence "the University authorities or the Government," on which occasions they would "usually carry the day." ${ }^{41}$ As leader of the Canada First movement, however, Blake probably opted to reserve exercizing his influence for Canadian-born candidates in future competitions (commencing the following year with Loudon's).

In conclusion, then, combining the prestige of his parliamentary seat and university offices, Vice-Chancellor Thomas Moss emerges as arguably the most influential advisor to Oliver Mowat vis-à-vis the 1874 competition for the Natural History Chair. The weight of probability is that Thomas Moss conveyed to the Premier a consensual recommendation from their alumni caucus that proved decisive for the outcome. During his ministry Mowat garnered a reputation for making vital, senior appointments for partisan political reasons. Historian Thomas Brown noted another example that occurred just one year later, in 1875, concerning Mowat's selection of Dr. Daniel Clark as Superintendent of Toronto's Provincial Asylum: "Indeed it is difficult to escape the conclusion, given [Clark's] lack of experience in handling the insane, that his appointment was little more than a political reward by the Liberal government of Oliver Mowat for Clark's active support for the Grit cause in the riding of North Oxford." ${ }^{42}$

Another historical factor from their student days may have contributed to 
favouring Wright's candidacy. Their earlier displeasure at labouring under the tutelage of Professors Hincks and Cherriman, combined with their strongly pro-evolutionist views, left them chafing mightily that the University and government in $1853 \mathrm{had}$ bypassed the self-same two scholars who had since emerged as Charles Darwin's foremost disciples and propagators - the aforementioned Thomas Henry Huxley and John Tyndall. The former had become known as "Darwin's bulldog," initially by confronting the prominent Creationist defender, Bishop Samuel Wilberforce in a rancorous, 1860 academic altercation. Tyndall, for his part, had just recently turned up the ideological heat through his infamous pro-materialism Belfast address as President of the British Association for the Advancement of Science, during August of 1874, in the midst of this Toronto selection process. Tyndall had "traced life's origins to inorganic compounds and even single atoms. Darwin's organic theory paled in comparison.” ${ }^{43}$ Appointing Ramsay Wright, who was positioned as a young evolutionist respectably trained at Edinburgh in experimental lab research, may have seemed like an opportunity to avoid repeating, or possibly even to atone for, the perceived misjudgments of two decades earlier when U. of T's and the government's selection process resulted in the rejection of both Huxley and Tyndall as science chairs.

For his part, Wright's personal resources and professional credibility available for marshalling into the competition seem to have been sparse, almost chimerical. Although neither his own application documents nor a fonds d'archives of his career correspondence and other papers have survived in archival repositories on either side of the Atlantic, his circumstances in 1874 Edinburgh are known from institutional records, documentary fragments and family lore. ${ }^{44}$ Inferentially, a letter of reference from either his eminent graduate supervisor, Professor Wyville Thomson, or the latter's renowned close associate, T.H. Huxley, could very likely have tipped the balance in Wright's favour; yet the possibility of both must be ruled out. Thomson was famously leading the renowned HMS Challenger oceanography expedition, circumnavigating the globe on the high seas (at the Fiji Islands during August, 1874 ${ }^{45}$ ), hence was inaccessible for more than three years, from December, 1872 until the ship's return in May, 1876. Huxley's archival fonds has survived quite comprehensively, in the archives of his own (successor) institution, the Imperial College of London; however it includes no correspondence with Ramsay Wright, nor any concerning him. ${ }^{46}$

Two 1874 letters that came to light almost a century later, sent to Wright's Zoology Department successors for their departmental history, lend support to the picture of him as an isolated, unlikely choice. In a letter to his financial patron and uncle, John Ramsay, during February of 1874, just before the launch of Toronto's competition, young Wright explained that he had just been appointed to, but had not yet begun his first junior faculty role, as "assistant to the Professor of Natural History in this [Edinburgh] University and enter on my work in May under Dr. [Julius Viktor] Carus of Leipzig, who is to lecture for Prof. Wyville Thomson. My duties as such are to preside over a practical class and to demonstrate microscopic forms. ${ }^{.47} \mathrm{He}$ requested a loan to purchase a microscope; and another loan in a second (September) letter via his mother for making his way across the ocean to Toronto. John Ramsay also supported Wright's living expenses during his initial year in Toronto until he 
received his first salary payment. ${ }^{48}$ Clearly he lacked the benefit of an active sponsor or patron in Toronto. So there seems reasonable grounds to conclude that Wright, carrying no rival baggage such as from McGill or Queen's, was plucked from tender obscurity and invested with the qualities and expectations, or particularistic criteria, that Toronto's alumni cabal desired.

The immediate irony in the selection of Ramsay Wright is that an application of universalistic criteria would have resolved instead upon Professor George Lawson as not just demonstrably the most qualified candidate, but one who had himself quietly pursued evolutionist themes through his extensive research over the preceding decade. Historians Suzanne Zeller and Carl Berger have documented that Lawson was no Linnaean blackboard traditionalist in the perceived "Rev. William Hincks" mold. Had those who influenced the Premier in his selection taken the trouble to look more deeply into Lawson's work, they would have been pleasantly surprised at the direction of his respected, Darwinian-era research. Darwin's chapters XI and XII of $O n$ the Origin of Species are expositions of Geographical Distribution, in which he observed that:

If the difficulties be not insuperable in admitting that in the long course of time the individuals of the same species, and likewise of allied species, have proceeded from some one source; then I think all the grand leading facts of geographical distribution are explicable on the theory of migration (generally of the more dominant forms of life), together with subsequent modification and the multiplication of new forms. ${ }^{49}$

Basing his efforts on the work of the eminent British evolution botanist, J.D. Hooker's theory of "creation by variation," Lawson had pursued the geographical distribution of certain species that migrated and adapted to new environments - in Canada and British North America, rather than abroad - which accorded with, and scientifically advanced the current Darwinian thinking, while directly conflicting with the traditional religious belief in special creation and the fixity of species. ${ }^{50}$ "In particular, Lawson verified Hooker's bio-geographical theory that northern plant forms spread farther south along the Atlantic coast than inland, and that Canadian [Province of Canada, i.e., Ontario and Quebec] swamp plants flourished along east-coast hillsides." ${ }^{1}$ Lawson subsequently pursued this line of inquiry through studying the variation, adaptation and survival of Canadian Arctic flora in comparison with that of northern Europe. ${ }^{52}$

\section{The Wright Stuff: Apostle or Missionary?}

Lacking the context of a fonds d'archives for Wright, historians assessing his scholarly legacy have been handicapped in tracing its origins and development, and in assessing its outcomes. ${ }^{53}$ Regrettably, Wright generally gave short shrift or none in his publications to illuminating the evolution of his ideas and their sources. Without the basis for analyzing Wright's scientific journey — his early grounding, career evolution 
and ultimate contributions - the few historical accounts have relied upon scattered, mostly celebratory reminiscences by a handful of his students, friends, colleagues and other admirers. Recollections found in Wright's obituaries, in accord with custom for that format, are inclined to accentuate the positive. ${ }^{54}$ Those and similar mentions found within his students' and colleagues' memoirs focus overwhelmingly on the favourable regard in which he was held for his charismatic teaching and mentoring attributes, along with his high visibility in senior administrative roles. The respected latter-day authority on history and ideas in Canadian higher education, A.B. McKillop, has characterized Wright as an "apostle" of the research ideal and the methodological rigour of the laboratory. ${ }^{55}$ But was he an apostle — or rather, having largely removed himself from the centre of biological knowledge creation, was he more of a missionary, helping to bring word of the scientific "paradigm shift" ${ }^{56}$ from across the sea?

By 1901 Wright had been appointed by the provincial Liberals as Dean of Arts and the university's first and only Vice President, while continuing as the biology professor in both Arts and Medicine. He had focused externally on the field of aquatic biology in Canada while mentoring exceptional Toronto undergraduates, such as by facilitating a postgraduate path to Johns Hopkins. Internally as well he continued developing the curricula along with a lively esprit de corps in the 1889 Biology Building as the professional home for science students (especially zoology) in both Arts and Medicine.

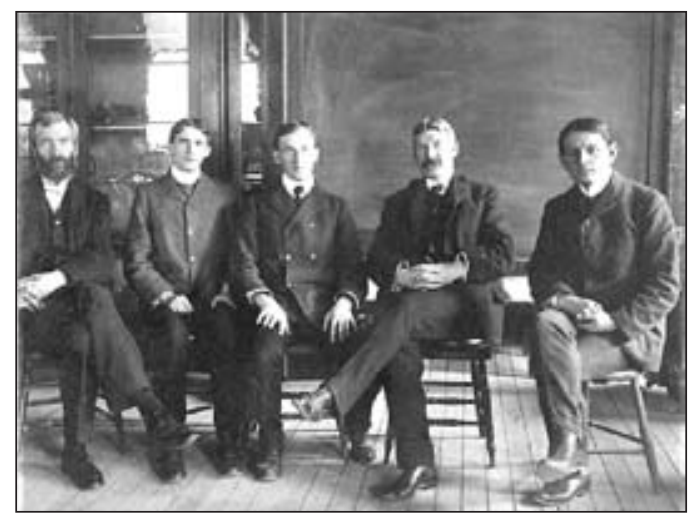

Fig. 3: Profs. A.B. Macallum (left) and Ramsay Wright (2nd right) with medical students in the Biology Building, 1902 (UTA, B77-0040, Series II (01), silver gelatine photoprint).

Loudon was persuaded through provincial pressure to resign as President in 1906. Wright had remained hopeful of succeeding to the university's presidency, however he was "bitterly disappointed," 57 securing only one strong recommendation. By 1911 he became seized of the notion that eugenics was one of the "new sciences" emerging from biology, bestowing it with legitimacy in no less a prestigious context than his Presidential Address that year to the annual meeting of Canada's Royal Society. ${ }^{58}$ Wright cited its origins with the recently-deceased Sir Francis Galton and its progress via Galton's statistician disciple, Karl Pearson. He then launched into the familiar themes of finger-pointing, alarm and undisguised contempt for many of society's most 
vulnerable and disadvantaged groups. Wright concluded his Presidential Address to the country's intellectual elite by admonishing them that "some of the causes of decadence may undoubtedly be counteracted by the judicious application of sound eugenic principles, and any nation will do well to give these serious consideration." 59

While discussing controversial matters in rarified academic settings is common and even de rigueur, shortly thereafter, Wright went public with his advocacy campaign for eugenic solutions. Reported in the press under headlines such as, "Would Purify Canadian Race," and "Be Careful in Choosing Parents," on a July evening in 1911 he filled the university's new Physics Building auditorium, delivering fear-filled messages against "the polyglot populations of immigrants," criminal offenders, the mentally ill and other "bad strains of stock." 60

Subsequently, whether arising or not from Wright's public address and the ensuing media reports, at least four of his former medical students, two of whom were also junior lab associates and admirers, became actively involved with the eugenics movement. Dr. Clarence Hincks ${ }^{61}$ co-founded with medical Dean C.K. Clarke in 1918 the Canadian National Committee for Mental Hygiene (CNCMH). ${ }^{62}$ By 1920 they were publicly displaying a slogan that "only the mentally and physically fit should beget and bear children." ${ }^{63}$ Hincks remained a staunch eugenics advocate until he died; for example, authoring a Macleans national magazine article in 1946 entitled "Sterilize the Unfit." ${ }^{64}$ Dr. A.G. Huntsman, another of Wright's prominent former students, was a member of the Advisory Council of the American Eugenics Society which, as with the $\mathrm{CNCMH}$, advocated enacting eugenics legislation. ${ }^{65} \mathrm{~A}$ third former medical student, Dr. Helen MacMurchy, was a consistent eugenicist who served as Ontario's "Inspector of the Feebleminded" in the 1910s, and later published praise for the Third Reich's sterilization policy in $1934 .{ }^{66}$ The fourth former medical student was considerably more active and visible in the 1930s. Dr. Herbert Bruce, had by then become founder of Toronto's Wellesley Hospital, Lieutenant Governor of Ontario, and a fervid eugenicist. In addressing a 1936 Social Welfare Conference in Toronto Dr. Bruce remarked approvingly that: "Fifty thousand idiots have been sterilized in Germany who will henceforth be unable to have idiot children." ${ }^{67}$ Regardless of the extent to which Wright had a direct impact on these and other eugenicists, his public propaganda helped set the larger stage with a veneer of apparent legitimacy for their nation-wide campaign.

\section{Reflections on Wright's Legacy}

Any university's educational, research and knowledge missions are reliant for continuing support upon its reputation, which springs in large part from its mythology as well as the actual experiences of its past. Hence the understandable temptation among its champions to look to its history for heroic figures. Far too few are the William Oslers, about whom Professor Bliss found that: "To a modern biographer looking for a subject's warts and failings it is disconcerting to find that the Osler of history was a man who for the most part lived up to his shining image." ${ }^{68}$ Ramsay Wright enjoyed wide renown as a classroom teacher, mentor and motivational public 
speaker. Everyone who spoke of him said so, without reservations - from Toronto's college freshmen, to a future prime minister, Mackenzie King (who was successively both). In 1901 while Deputy Minister of Labour, King prefaced a diary entry about a Mrs. Herridge, "who was much inclined to laugh as usual and behave badly," and other women in the audience, by opining that Wright's public lecture at the Ottawa Normal School on "Malaria and Mosquitoes" was most interesting, "delivered exceedingly well, without notes, in a popular and yet cultured manner. I thought Wright did credit to the University and showed to firstrate [sic] advantage. His manner is very English, but that is an excusable fault." ${ }^{69}$

In his lengthy Toronto career Wright was consistently admired as a gifted lecturer, memorably presenting his material with a lucidity that connected his audiences, sometimes inspirationally, to often-microscopic zoological life. He also lent support energetically to a range of senior colleagues who took the academic lead for establishing new scientific programs, both within the university (engineering and medicine) and at marine biology stations. His high school textbook helped introduce Darwinian evolution to Canadian schools. Yet latter-day scholars as well as Wright's contemporaries have on occasion been inclined to wax overly effusive in their claims for him, along the lines of his having "devoted his efforts wholeheartedly..." to ultimately "influence research and teaching throughout North America." ${ }^{70}$ As to research, clearly his activity peaked during the 1880s. Dr. Sylvia Bensley, two of whose in-law relatives were (successively) students, close colleagues and, for one, the immediate successor to Wright as Biology Head, wrote concerning the 1890s decade, that: "Although Professor Wright took no part in research and very little in laboratory work, he was a superb and inspiring lecturer." ${ }^{\prime 1}$

Wright's advantages and activities suffused his public persona with an admiring, sympathetic glow, evidently sufficient to eclipse his missteps such as the 1911 eugenics campaign, and earn for him a century of adulation and commemoration in Toronto. ${ }^{72}$ In 1965 the university reached back into its past for naming the imposing Ramsay Wright Zoological Laboratories edifice after an iconic forerunner. This article's retrospective assessment is not for judging Wright, whether positively or negatively, but to assert that whatever reasons prevailed for his selection through the 1874 recruitment competition remain mysterious and hence open to critical analysis. In this context we conclude that, notwithstanding Wright's many exceptional qualities that emerged and gave him considerable visibility during his career, an open and transparent competition in 1874 would almost certainly have resolved upon one of the several more qualified and experienced candidates. More broadly, Kathleen McConnachie ${ }^{73}$ has advised historians to be cautious in selecting individuals as exemplary role models, or alternatively as unusual (such as her subject, Helen MacMurchy, vis-à-vis eugenics) for having promoted ideas that were in fact widely held among certain professional elites. Rather, we should seek an understanding of subjects' contextual relationship to the scientific ideas and traditions of their time and place in history. 


\section{Notes}

1 Anon., Ottawa Times, reprinted in [Ontario] Journal of Education, 27:12 (Dec. 1874), 179.

2 John P.M. Court, "An Erosion of Imagination: Unfulfilled Plans for a University Botanical Gardens and Taddle Creek, 1850 to 1884," Ontario History, 95:2 (Autumn 2003), 166-91.

3 For example, U. of T's Botany Department historian wrote that Wright as Head of the combined Natural History/ Biology Department from 1874 to 1912 showed "little real interest in botany": Dorothy F. Forward, The History of Botany in the University of Toronto (Toronto: University of Toronto Press, 1977), 4-5. E.C. Jeffrey and R.B. Thomson, two botany faculty members under his jurisdiction, recorded sundry criticisms of Wright's efforts to marginalize botany: John P.M. Court, "Darwinian Evolution's First Fifty Years of Impact on Botany at the University of Toronto, 1859 to 1909," Ontario History, in review.

4 The Globe and Mail (Toronto), 8 April 2006, F8.

5 R. Ramsay Wright, An Introduction to Zoology for the Use of High Schools (Toronto: Copp Clark Co. Ltd., 1889), courtesy Ontario Historical Education Collection, Library of the Ontario Institute for Studies in Education, University of Toronto (OHEC, OISE-UT). Through this textbook, "Wright presented organic evolution as the principle integrating the whole field." Carl Berger, Science, God, and Nature in Victorian Canada (Toronto, Buffalo, London: University of Toronto Press, 1983), 75.

6 Suzanne Zeller, Land of Promise, Promised Land: The Culture of Victorian Science in Canada (Ottawa: Canadian Historical Association, Historical Booklet No. 56, 1996), 18. "The third phase, after the mid-1880s, witnessed a remarkable profusion of positive references to Darwin. This fanning-out process began slowly, as Ramsay Wright's Introduction to Zoology (1889) permeated Canadian High schools." Botany had long been taught in Ontario high schools when zoology was introduced for the upper grades in 1888: Ramsay Wright, "Introduction of Zoology into High Schools," in The Canada Educational Monthly and School Magazine, Vol. 10 (Aug.-Sept. 1888), 254-6. Their texts were authorized by the Ontario Department of Education in "Circular 21" (later renumbered 14): OHEC, OISE-UT.

7 Wright, An Introduction to Zoology, 283, 285.

$8 \quad$ William Osler, "The Historical Development and Relative Value of Laboratory and Clinical Methods in Diagnosis: The Evolution of the Idea of Experiment in Medicine" (1907), reproduced in Charles Roland, ed., Sir William Osler, 1849-1919: A Selection for Medical Students (Toronto: Hannah Institute for the History of Medicine/ Irwin Inc., 1982), 103-4.

9 Ronald L. Numbers and John Stenhouse, eds., Disseminating Darwinism: The Role of Place, Race, Religion, and Gender (Cambridge, UK: Cambridge University Press, 1999).

10 University of Toronto Archives (UTA), Langton Family fonds, B65-0014/004, Sir Daniel Wilson's Journals, 7 March 1887, 112. Carl Berger records that there was some validity to Wilson's fears, although the reaction was largely confined to letters to the newspapers: Berger, Science, God and Nature, 68-9.

11 Berger, ibid., 60-1, 66. A.B. McKillop, Contours of Canadian Thought (Toronto: University of Toronto Press, 1987), chap. 4, 443-58.

12 Legislature of Ontario, University Senate Reform Act, 36 Vict. (April 1873), c.29, (The Crooks Act). A.B. McKillop, Matters of Mind: The University in Ontario, 1791-1951 (Toronto: Ontario Historical Studies Series and University of Toronto Press, 1994), 152-4.

13 William James Loudon, Sir William Mulock: A Short Biography (Toronto: Macmillan of Canada Limited, 1932), 68. W.J. Loudon by this time was a U. of T. professor emeritus. 
14 W.J. Loudon, 69-70. Also quoted in McKillop, Matters of Mind, 112, and Robin Harris, A History of Higher Education in Canada, 1863-1960 (Toronto, 1976), 54. W.J. Loudon's book, 72, a notoriously sycophantic hagiography, credits Mulock and the author's late uncle, James Loudon, with beginning to rectify matters in 1876 by leading a campaign to persuade the Education Minister to fund the acquisition of one or more new microscopes.

15 UTA, James Loudon (1841-1916), B72-0031, "The Memoirs of James Loudon, President of the University of Toronto, 1892-1906," unpubl. ms., n.d. (ca.1907, deposited 1964). Contrary to the views of Loudon and Mulock on Hincks, and more aligned with the positive experiences of Osler, was the assessment of a later historian of the Zoology Department: "Professor Hincks was no mere lecturer from books and museum specimens but was an active thinker and contributor to the culture of his period, as is indicated by a list of his publications during his occupancy of the chair..." E. Horne Craigie, A History of the Department of Zoology of the University of Toronto up to 1962 (Toronto: University of Toronto Press for the Department of Zoology, 1972), 9.

16 McKillop, Matters of Mind, 153-4.

17 In 1874, while the academic competition considered here was under way, the Toronto Globe reported on the House of Lords' debates on a Government Bill for "the abolition of all Church patronage from the Crown downwards" in Scotland (with the danger of setting a precedent for England astutely noted), designed to democratize the appointment of Church of Scotland clergy. To ease the transition they proposed to continue the tradition of an appointee "compensating patrons" with a sum equivalent to his first year's stipend. The Daily Globe (Toronto), 10 June 1874, 4.

18 An Act to amend the Charter of the University established at Toronto by His late Majesty King George the Fourth, to provide for the more satisfactory government of the said University ... Provincial Parliament of Canada, III - $1^{\text {st }}$ Session: 11-12 Vict., Cap. 82, 1849 (The Baldwin Act). In describing this statute's novel legislative provisions for appointing faculty through fairness and objectivity, Archibald B. Macallum maintained that this ought to have led to favourable outcomes for two (later-renowned) 1851-53 candidates who instead were passed over: "Huxley and Tyndall and the University of Toronto," The University of Toronto Monthly, 2:3 (Dec. 1901), 68-76.

19 R.D. Anderson, European Universities from the Enlightenment to 1914 (Oxford: Oxford University Press, 2004).

20 Max Weber, The Theory of Social and Economic Organizations, transl. A.M. Henderson and Talcott Parsons, ed. and Introduction by Talcott Parsons (New York: The Free Press, 1947), 73, 80, 82.

21 Macallum, "Huxley and Tyndall," 70.

22 The Daily Globe (Toronto), 12 June 1874, 4. Eugene Emil Felix Richard Haanel (1841-1927), Ph.D. (physics and mineralogy, Breslau) was "one of the first European scientists to teach in Canada." Dictionary of Canadian Biography (DCB) XI, entry for Samuel S. Nelles.

23 McKillop, Matters of Mind, 88, citing Janet C. Scarfe, Letters and Affection: The Recruitment and Responsibilities of Academics in British North American Universities in the Mid-19th Century (PhD diss., University of Toronto, 1982).

24 Macallum, "Huxley and Tyndall," 68-76. The 1850s' rejections of both Huxley and Tyndall have continued to rankle at U. of T.; e.g., Martin Friedland, The University of Toronto: A History (Toronto: University of Toronto Press, 2002), 48-9, 671.

25 McKillop, Matters of Mind, 154-5.

26 Archives of Ontario (AO), Provincial Secretary's Office Correspondence, RG 8-1-1-D, letters of 26 March 1874 (File 656), 8 April 1874 (File 527) and May, 1874 (File 854).

27 AO, Provincial Secretary, ibid., File 1051 for Andrew Leith Adams, MA, MB of London, UK; File 1094 for Henry Major of Nottingham, UK; File 1360 once 
existed for Robert Ramsay Wright, per the alphabetical File Index Register (now on microfilm) created annually by the Provincial Secretary's Office-however, this file was subsequently lost, likely (according to AO staff) before transfer of that records series to the AO; and File 1455 for Rev. Alexander F. Kemp, LL.D. [1822-1884, originally from McGill but then at Knox College, Galesburg, Ill., USA]. For Wright's qualifications and experience up to 1874, see: UTA, Greer Clippings/Bio File for Wright; his biographical summaries as authored/ edited in The Globe (Toronto), 21 Aug. 1897, 3, and Henry Morgan (ed.), Canadian Men and Women of the Time (Toronto, 1912), 1189; and Craigie, Department of Zoology.

28 AO, Provincial Secretary, ibid.: File 950 for candidate Robert Bell [1841-1917]. Also see W.A. Waiser, entry for Robert Bell in DCB, XIV, 55-6.

29 AO, Provincial Secretary, ibid.: File 656 for candidate Robert Brown - not the Robert Brown (1773-1858) whom Penhallow cited as having instigated "the so-called Brownian movement": D[avid] P[earce] Penhallow,"A Review of Canadian Botany from 1800 to 1895," Proceedings and Transactions of the Royal Society of Canada, $2^{\text {nd }}$ Series, Vol. III (1897), Section IV, 3-56, 30.

30 Court, "An Erosion of Imagination," 170-1, 187 n.45.

31 AO, Provincial Secretary, File 527 for candidate George Lawson.

32 Dalhousie University Archives, MS 2-159/ 2-381, "Application and Testimonials on behalf of George Lawson, LL.D. as a Candidate for the Professorship of Natural History in University College, Toronto, 25 April 1874," 19 pp. Also see: Jacques Rousseau et William G. Dore, "L'Oublié de l'histoire de la science canadienne-George Lawson, 1827-1895" in G.F.G. Stanley, ed., Pioneers of Canadian Science: Symposium presented to the Royal Society of Canada in 1964 (publ. for the Society by University of Toronto Press, 1966), 54-80 and App. B; and Suzanne Zeller, entry for George Lawson, DCB, Vol. XII, 539-43.

33 UTA, Langton Family fonds: Sir Daniel Wilson's Journals, 17 October 1883 (quotation regarding Mowat) and 21 April 1874 (regarding Mowat, McCaul and Crooks).

34 "Enemies within the Gates," in Averill and Keith, "Daniel Wilson," 150-2. Friedland, The University of Toronto: A History, "Saving the University," Chapter 7, 64-74.

35 AO, Provincial Secretary, File 656 for candidate Robert Brown: Brown wrote to Mowat, 30 June 1874, that in addition to applying for himself, "Professor Alleyne Nicholson has already sent in an application for the Chair in Natural History on my behalf."

36 AO, Provincial Secretary, File 950 for candidate Robert Bell, letters, Bell to Hon. O. Mowat ("private"), 18 June 1874, and to the "Rev. Prof. Mowat, Kingston," 11 July 1874. Cf. Waiser's entry for Bell in the DCB, noting that in later years Bell was "stubborn and arrogant" and "continually plotted against his GSC director."

37 David N. Livingstone, "Science, Region, and Religion: The Reception of Darwinism in Princeton, Belfast, and Edinburgh," in Numbers and Stenhouse, Disseminating Darwinism, 16.

38 James Loudon, The President's Report for 1899-1900 (University of Toronto), quoted in Craigie, Department of Zoology, 9.

39 P. Roome, "The Darwin Debate in Canada, 1860-1880," in Louis A. Knafla et al., eds., Science, Technology, and Culture in Historical Perspective (Calgary: University of Calgary, Studies in History No. 1, 1976), 196-7; McKillop, Contours, chap. 5, 59-77 and 1994, 181-2; and C.G. Holland, entry for William Dawson LeSueur (1840-1917) in $D C B$, Vol. XIV, 650-2.

40 Averill and Keith, "Daniel Wilson," 155. Also see J.G. Snell, entry for Thomas Moss (1836-1881) in DCB, Vol. XI, 621-2.

41 W.J. Loudon, 68-9.

42 Thomas E. Brown, Living with God's Afflicted: A History of the Provincial Lunatic Asylum at Toronto, 1830-1911 (PhD diss., Queen's University, History, 1980), 236. 
43 Zeller, "Land of Promise," 17. Also see "John Tyndall" in the Oxford Dictionary of National Biography. A.B. McKillop, Contours, 67, astutely commented that: "The very phrase 'Belfast Address' became synonymous with words, such as 'materialism,' which were seen to pose dire threats against orthodox religious belief. This was no less the case in the new Canadian nation than it was in the more serene atmosphere of the English parsonage."

44 John P.M. Court, DCB XVI, in press, entry for Robert Ramsay Wright, through the courtesy of the $D C B$. Wright's only documentary gift or deposit was the bequest to $\mathrm{U}$. of T's Library of a typescript of his retirement project, viz., a translation of a work of medieval Persian astronomy (1029 AD) by M. Al-Biruni: U. of T. Library, Fisher Rare Book Room, ms 5123.

45 T.H. Tizard, RN et al., Narrative of the Cruise of H.M.S. Challenger: Report, Vol. 1, Part 2 (1885), 65.

46 Imperial College Archives: no mention of Wright was found in the comprehensive T.H. Huxley fonds, "either as a correspondent or as mentioned in any of Huxley's correspondences." E-mail memo from Hilary McEwan, Special Collections Archivist, Imperial College, London (UK) to the writer, 7 April 2006.

47 R. Ramsay Wright, letter to his maternal uncle, John Ramsay of Kildalton, 18 Feb. 1874, reproduced in App. B, "Additional Notes on R. Ramsay Wright" in Craigie, Department of Zoology, 79. Neither Wright nor his later associates ever identified any academic mentors for him in Scotland other than Wyville Thomson, nor a benefactor or patron other than his uncle.

48 Janna Ramsay Best (a descendant of John Ramsay of Kildalton), personal communication, 3 July 2009. For the family genealogy, see: Freda Ramsay, John Ramsay of Kildalton, M.P. (Toronto: Peter Martin Associates Limited, 1969).

49 Charles Darwin, On the Origin of Species by Means of Natural Selection... (London: John Murray, 1859), 408.

50 Subsequently one of Wright's botanist junior colleagues defined "the dogma of special creation and the fixity of species. Each species was a platonic idea expressed at some time or other by the creator, and not linked to any others by intergrading or connecting forms." J. H. Faull, "The Influence of Darwin on Botanical Science," Ontario Natural Science Bulletin, 5 (1909), 32.

51 Suzanne Zeller, "Environment, Culture, and the Reception of Darwin in Canada, 1859-1909," in Numbers and Stenhouse, "Disseminating Darwinism," 96, 101-2. Also see: Zeller, "Land of Promise," 16-7; and Zeller, DCB entry for George Lawson,

52 Berger, Science, God and Nature, 72, and Dalhousie University Archives, "Lawson Testimonials."

53 Court, $D C B$ XVI (in press), Robert Ramsay Wright.

54 It is interesting to compare one sunny comment from another Canadian eugenicist's obituary with a recent journal article's more contextual interpretation: "When Dauphinee died... she was called 'a pioneer teacher of Vancouver's retarded children.' However, she was also an advocate for a eugenic strategy of educational segregation, institutionalization, and sterilization of those children deemed to be feeble-minded." Gerald Thomson, "Through no fault of their own': Josephine Dauphinee and the 'Subnormal' Pupils of the Vancouver School System, 1911-1941," Historical Studies in Education, 18:1 (2006), 51-73, 52.

55 McKillop, Matters of Mind, 77.

56 R.D. Gidney and W.P.J. Millar, "The Reorientation of Medical Education in Late Nineteenth-Century Ontario: The Proprietary Medical Schools and the Founding of the Faculty of Medicine at the University of Toronto," Journal of the History of Medicine, Vol. 49 (Jan. 1994), 75, acknowledging that the phrase "has become something of an academic cliché."

57 Craigie, Department of Zoology, 14. 
58 Ramsay Wright, "Presidential Address: The Progress of Biology," Royal Society of Canada Proceedings and Transactions, $3^{\text {rd }}$ Series, 5(1911), App. A, 37-48.

59 Wright, ibid., 43.

60 The Mail and Empire, 19 July 1911; also reported consistently in that day's edition of The Globe, 8. Two weeks later in a religious denominational periodical, an editorial set aside Wright's strident heredity and eugenics' rhetoric in calling for the study and amelioration of urban slums ("The Civic Cancer"), citing Wright's references to their containing large immigrant populations while contextualizing the problems as social, environmental and public health issues: The Presbyterian, New Series, 19:5 (3 Aug. 1911), 108.

61 Charles G. Roland, Clarence Hincks: Mental Health Crusader (Toronto: Hannah Institute and Dundurn Press, 1990). Conjointly with his Canadian activities, Hincks was Medical Director of the U.S. National Committee for Mental Hygiene based in New York, 1931-39.

62 Angus McLaren, Our Own Master Race : Eugenics in Canada, 1885-1945 (Toronto: McCelland \& Stewart, 1990).

63 Montreal Star, 20 May 1920, 2, "Baby Welfare has Mental Hygiene Booth."

64 Macleans magazine, 15 Feb. 1946.

65 UTA, Huntsman fonds, B2005-0006/009(11).

66 William H. Brown, Making Representation: Dr. Helen MacMurchy and the "Feebleminded" in Ontario, 1906-1919 1910 (PhD diss., U. of T./ OISE, 2005), chap. 7 and 260.

67 CAMH Archives, Canadian Mental Health Assn. (CMHA) fonds, Eugenical Sterilization files, "Sterilization Notes" pamphlet, 5.

68 Michael Bliss, "William Osler at 150," CMAJ, 161:7 (5 Oct. 1999), 833. Also see in the same edition: Charles G. Roland, "Reputation Unrevised: Celebrating the Osler Sesquicentennial," 827-8.

69 Library and Archives Canada (LAC), Diaries of William Lyon Mackenzie King, G1608, Sat., 30 March 1901, 61 (handwritten p.89), ArchivariaNet online.

70 Sandra F. McRae, The 'Scientific Spirit' in Medicine at the University of Toronto, 1880-1910 (PhD diss., University of Toronto, 1987), 104.

71 Dr. Sylvia H. Bensley, "Notes on R. R. Bensley and the Department of Biology, 1892 to 1901," in Craigie, Department of Zoology, App. C, 81. Also see McRae, The 'Scientific Spirit, 112, who considered this a "rather misleading assessment" for neglecting mention of Wright's research work in the 1880s.

72 Wright has been accorded heroic status in the University of Toronto's institutional histories, notably: W. Stewart Wallace, A History of the University of Toronto, 1827-1927 (U. of T. Press, 1927), 184; E. Horne Craigie (1972); Paul Bator and A.J. Rhodes, Within Reach of Everyone: A History of the University of Toronto School of Hygiene and the Connaught Laboratories (Ottawa: Canadian Public Health Assn., 1990), 4; and Martin Friedland, The University of Toronto: A History (2002), chaps. 8, 12. The most extensive scholarly assessment of Wright's career appeared in Sandra F. McRae's thesis, The 'Scientific Spirit' in Medicine, 1987. McRae identified the forces that culminated in 1887 with re-establishing the U. of T. medical school as a teaching faculty after 34 years, crediting Wright with his share (and perhaps more) of the credit. Gidney and Millar felt that McRae's otherwise stimulating thesis was marred, reflecting the biases of the extant literature, by denigrating the privately-operated medical schools "and to assume that only the 'reformers' [including Wright] were on the right track": Gidney and Millar, "Reorientation of Medical Education," 52 n.1. All of these historical analyses overlooked Wright's 1911 public and professional tangent in fervid support of the eugenics movement, although it was widely reported by the popular press (Toronto, The Globe, and The Mail and Empire, 19 July 1911; The Presbyterian, 3 Aug. 
1911) as well as through Wright's Presidential Address in the Royal Society of Canada's Proceedings and Transactions (1911).

73 Kathleen McConnachie, "Methodology in the Study of Women in History: A Case Study of Helen MacMurchy, MD," Ontario History 75:1 (1983), 61-70. 